\title{
MENINGKATKAN KEMAMPUAN LITERASI DIGITAL GURU BAHASA INGGRIS MELALUI PEMBUATAN MEDIA PEMBELAJARAN INTERAKTIF
}

\author{
${ }^{1 *}$ Rika Riwayatiningsih, ${ }^{2}$ Yunik Susanti, ${ }^{3}$ Sulistyani, ${ }^{4}$ Mahendra Puji PA \\ Universitas Nusantara PGRI Kediri, Kediri, Indonesia \\ Email : ${ }^{\text {rieka@unpkediri.ac.id }}$
}

Manuskrip: Desember -2021; Ditinjau: Desember -2021; Diterima: Desember -2021; Online: Januari-2022; Diterbitkan: Januari-2022

\begin{abstract}
ABSTRAK
Kegiatan Pengabdian kepada Masyarakat $(\mathrm{PkM})$ ini berupa edukasi literasi digital dalam pembuatan media pembelajaran interkatif bagi guru Bahasa Inggris SMP di Kabupaten Nganjuk. Kegiatan ini dilatarbelakangi beberapa permasalahan yang dihadapi oleh para guru Bahasa Inggris, Dengan dilaksanakannya keguatan PkM edukasi literasi digital ini diharapkan dapat mencapai tujuan sebagai berikut: 1) meningkatkan literasi digital dalam pembuatan media pembelajaran interaktif; 2) meningkatkan motivasi guru-guru Bahasa Inggris SMP di Kabupaten Nganjuk dalam mengembangkan media pembelajaran interaktif berbasis digital sebagai bentuk inovasi pembelajaran; dan 3) meningkatkan keterampilan guru-guru Bahasa Inggris SMP di Kabupaten Nganjuk dalam mengembangkan media pembelajaran interaktif berbasis digital sebagai bentuk inovasi pembelajaran. Metode yang digunakan pada kegiatan ini berupa: angket sebelum dan sesudah perlakuan, edukasi literasi digital (tutorial), dan penugasan. Rangkaian kegiatan PkM edukasi literasi digital pembuatan media pembelajaran interaktif bagi guru-guru Bahasa Inggris SMP di Kabupaten Nganjuk berlangsung selama 5 bulan (Agustus Desember 2021). Data tentang kemampuan literasi dan respon guru-guru diperoleh dengan memberikan angket tertutup sebelum dan sesudah tutorial.
\end{abstract}

\section{Kata Kunci: Literasi Digital, Media Pembelajaran Interaktif, Pembelajaran Bahasa Inggris}

\section{PENDAHULUAN}

Guru merupakan pendidik professional dengan tugas utama mendidik, mengajar, membimbing, mengarahkan, melatih, menilai, dan mengevaluasi peserta didik di berbagai tingkatan pendidikan, mulai dari pendidikan anak uasia dini hingga Sekolah Menengah Atas sejerajat (SMA/SMK/MA). Sebagai pendidik professional yang merupakan garda terdepan dalam system pendidikan guru dituntut untuk memiliki dan meningkatkan kompetensi secara berkelanjutan melalui berbagai bentuk, diantaranya penguasaan terhadap materi pelajaran yang diajarkan juga kemapuan menyampaikan materi ajar tersebut kepada siswa agar 
siswa mampu menguasai konsepsi keilmuan yang baik (Pemerintah RI, n.d.). Oleh karenanya salah satu indicator guru professional ditunjukkan dengan pengiasaan terhadap materi pelajaran dan kemampuan menyampaikan materi tersebut kepada siswa sehingga capaian pembelajaran yang telah ditetapkan terpenuhi dengan baik.

Pada era revolusi industry 5.0 dan menyongsong dimulainya era revolusi 5.0 seperti sekarang ini, sebagai seorang profesioonal guru dituntut untu bersikap adaptif dan responsive terhadap perkembangan teknologi dan informasi agar mampu menyesuaikan diri dan mampu memanfaatkan teknologi informasi (TIK) tersebut secara baik dalam pembelajaran. Pemerintah, terkait hal ini telah menggariskan bahwa pemanfaatan TIK dalam rangka pengembangan diri dan pemanfaatan TIK dalam pembelajaran sebagai salah satu syarat profesionalitas guru (Kemendikbud, 2017). Pemanfaatan TIK dalam pembelajaran pada gilirannya akan meningkatkan kompetensi siswa sebagai landasan pencapaian generasi emas 2045 dalam wujud siswa yang cerdas, kreatif, dan inovatif yang sebagai sumber daya manusia unggul yang diperlukan dalam pembangunan social dan ekonomi.

Salah satu inovasi pembelajaran yang harus dimiliki oleh guru terutama pada era digital seperti sekarang ini, terutama terjadi ketika diberlakukan Pembelajaran Daring pada masa Pandemi Covid-19, berupa keterampilan mendisain media pembelajaran interaktif berbasis digital. Namun secara empiris, hasil survey yang dilakukan oleh Tim Program Studi Pendidikan Bahasa Inggris FKIP Universitas Nusantara PGRI (UNP) Kediri menunjukkan bahwa media pembelajaran yang digunakan oleh mayoritas guru Bahasa Inggris SMP di Kabupaten Nganjuk berupa media pembelajaran konvensional, misalnya gambar, dan papan tulis. Ketika diberlakukan pembelajaran daring selama masa pandemic Covid-19, mereka hanya sebatas memanfaatkan media pembelajaran berbasis elektronik atau media social, dengan platform seperti: WA, Telegram, zoom meeting, dan google meet. Pemanfaat berbagai platform media tersebut hanya sebatas untuk keperluan: instruksi tugas, share materi pelajaran dalam bentuk ppt atau word, dan pengumpulan tugas. Kondisi seperti ini dapat mengakibatkan siswa menjadi bosan atau jenuh dalam menyelesaikan kewajibannya untuk belajar.

Berdasarkan permasalahan yang dihadapi oleh para guru Bahasa Inggris di Kota Nganjuk dan sekitarnya sebagaimana dipaparkan pada bab 1, maka dilakukan suatu kegiatan tertentu sebagai solusi berupa PkM edukasi literasi digital melalui pembuatan media pembelajaran interaktif. Kegiatan pelatihan serupa pernah dilakukan oleh (Hakim, Lefudin, Ratnaningdyah, \& Sugiarti, 2020) yang menghasilkan peningkatan keterampilan guru dalam pembuatan media pembelajaran interaktif. Beberapa penelitian terdahulu dan kegiatan pengabdian masyarakat juga menyatakan bahwa pemebrian pelatihan dapat meningkatkan 
motivasi dan kemampuan guru dalam pembuatan media pembelajaran interaktif dengan baik (Macromedia, Mx, \& Situasi, n.d.), (Firmadani, Shalima, \& Al Firdaus, 2017), (Pujawan \& Restami, 2018), (Lesmana et al., 2018), dan (Darmawiguna, Pradnyana, Santyadiputra, \& Pradnyana, 2019). Dengan dilaksanakannya keguatan PkM edukasi literasi digital ini diharapkan dapat mencapai tujuan sebagai berikut:

1. Meningkatkan literasi digital dalam pembuatan media pembelajaran interaktif;

2. Meningkatkan motivasi guru-guru Bahasa Inggris SMP di Kabupaten Nganjuk dalam mengembangkan media pembelajaran interaktif berbasis digital sebagai bentuk inovasi pembelajaran;

3. Meningkatkan keterampilan guru-guru Bahasa Inggris SMP di Kabupaten Nganjuk dalam mengembangkan media pembelajaran interaktif berbasis digital sebagai bentuk inovasi pembelajaran.

Beberapa permasalahan yang dihadapi oleh guru Bahasa Inggris SMP di Kabupaten Nganjuk sehingga mereka kurang memiliki keterampilan mengembangkan inovasi pembelajaran berupa media interaktif berbasis digital dalam pembelajaran bahasa inggris, berupa:

1) Literasi digital pembuatan media interaktif dalam mata pelajaran Bahasa Inggris masih belum memadai;

2) Kurangnya motivasi pada guru-guru Bahasa Inggris SMP di Kabupaten Nganjuk dalam mengembangkan media pembelajaran interaktif berbasis digital sebagai bentuk inovasi pembelajaran;

3) Keterampilan guru-guru Bahasa Inggris SMP di Kabupaten Nganjuk dalam mengembangkan media pembelajaran interaktif berbasis digital masih belum memadai.

Berbagai permasalahan sebagaimana dipaparkan di atas merupakan kondisi yang melatarbelakangi Tim PkM Prodi Pendidikan Bahasa Inggris berkolaborasi dengan MGMP Bahasa Inggris SMP Kabupaten Nganjuk melakukan kegiatan PkM dalam bentuk edukasi terkait literasi digital dalam pembuatan media pembelajaran interaktif sebagai upaya meningkatkan kualitas pembelajaran yang dilaksanakan secara daring bagi guru-guru Bahasa Inggris SMP di Kabupaten Nganjuk. Adapun tujuan dari diselenggarakannya pengabdian ini adalah meningkatkan kompetensi literasi digital guru dalam melaksanakan proses pembelajaran Bahasa Inggris di SMP dan yang sederajad guna memperbaiki kualitas pembelajaran sehingga mendapatkan lulusan yang lebih kompetitif. Pengabdian masyarakat ini memberikan pelatihan dan pendampingan bagi guru untuk meningkatkan ketrampilannya dalam menggunakan media digital yang lebih sesuai dengan kebutuhan siswa. Adapun tujuan spesifik dari kegiatan pengabdian kepada masyarakat ini adalah: 
1. Memperkenalkan media digital berupa digital book bagi guru-guru Bahasa Inggris SMP di kabupaten Nganjuk.

2. Menjelaskan penggunaan media pembelajaran digital book dan memberikan contoh materi dan cara menyusun bahan ajar Bahasa Inggris untuk siswa SMP.

3. Memberikan bimbingan pembuatan bahan ajar dengan menggunakan digital book untuk pembelajaran Bahasa Inggris yang menarik.

Adapun manfaat kegiatan ini minimal para guru Bahasa Inggris SMP di Kabupaten Nganjuk akan mengenal media digital book. Selain itu mereka akan Menyusun bahan ajar dengan lebih menarik dan lebih lengkap. Dengan bahan ajar yang menarik, siswa akan termotivasi untuk belajar Bahasa Inggris. Kegiatan ini juga dapat memacu semangat para guru untuk mengikuti perkembangan teknologi dan menerapkannya dalam pekerjaan profesionalnya setiap hari.Sasaran dari kegiatan ini adalah para guru yang masih perlu meningkatkan pengetahuan dan keterampilannya terkait dengan penggunaan media pembelajaran yang berbasis digital. Sasaran kegiatan ini yaitu para guru Bahasa inggris SMP di kabupaten Nganjuk. Jumlah perserta kegiatan ini sebanyak 71 orang yang bergabung dengan MGMP Bahasa Inggris di kabupaten Nganjuk

\section{METODE}

Metode pelaksanaan pada program pengabdian kepada masyarakat ini disusun secara sistematis. Adapun pelaksanaan kegiatan ini diuraikan dalam tabel berikut;

1. Persiapan

a. Wawancara dengan pembina dan ketua MGMP Bahasa Inggris SMP Kabupaten Nganjuk tempat pelaksanaan kegiatan

b. Pengurusan administrasi dan perijinan tempat pengabdian masyarakat

c. Persiapan materi edukasi dan kuesioner evaluasi

2. Pelaksanaan

Sasaran utama dalam kegiatan pengabdian masyarakat ini adalah para guru Bahasa Inggris sekolah menengah pertama (SMP) dan yang sederajad di kabupaten Nganjuk yang tergabung dalam Musyawarah Guru Mata Pelajaran (MGMP). Jumlah guru yang mengikuti kegiatan pengabdian masyarakat ini sebanyak 71 orang. Metode yang digunakan adalah workshop pembuatan media pembelajaran berupa digital book. Penyelesaian masalah pada guru-guru yang kurang memiliki ketrampilan menggunakan media digital dipandu Langkah demi Langkah mulai dari pengenalan aplikasi, cara kerja aplikasi, fitur-fitur aplikasi, kelebihan aplikasi hingga cara memanfaatkannya dalam memproduksi bahan ajar yang menarik. Kegiatan ini dilakukan 3 tahap, tahap pertama yaitu menjelaskan langkah-langkah tersebut di atas yaitu mulai dari pengenalan aplikasi hingga pemberian contoh dan mempraktikkannya. Tahap kedua adalah guru-guru diberi waktu kurang lebih dua minggu untuk membuat bahan ajar dengan menggunakan aplikasi digital book. Selama mereka melakukan tugasnya pendampingan sambal terus diberikan kepada peserta pengabdian melalui 
telegram group. Pada tahap berikutnya lima guru sebagai perwakilan mendemonstrasikan hasil praktek pembuatan buku digital satu persatu. Pemateri memberikan umpan balik serta saran atau komentar terkait hasil pembuatan digital book mereka

3. Evaluasi

Di akhir sesi pendampingan diadakan evaluasi pelaksanaan kegiatan untuk mengidentifikasi capaian, hambatan, dan lesson learned (best practice) atas kegiatan pengabdian masyarakat ini.

4. Teknik Penyelesaian Masalah (terdapat alat ukur ketercapaian)

Metode pelaksanaan kegiatan PkM edukasi literasi digital pembuatan media pembelajaran interaktif bagi guru-guru Bahasa Inggris di Kabupaten Nganjuk ini meliputi tahapan atau langkah-langkah sebagai berikut;

a. Pre-Intervensi Kuestioner

Kegiatan ini bertujuan untuk mengetahui tingkat pengetahuan dan pemahaman peserta terkait literasi digital media pembelajaran interaktif.

b. Edukasi Literasi

Kegiatan ini diberikan dalam bentuk tutorial guna memberikan edukasi kepada peserta agar memiliki pengetahuan dan pemahaman yang memadai terkait hal ikhwal media pembelajaran interaktif berbasis digital. Materi edukasi literasi ini terdiri atas:

1) Problematika pendidikan dan pembelajaran Bahasa Inggris di sekolah;

2) Model-model pembelajaran;

3) Pemilihan media pembelajaran yang sesuai dalam pembelajaran Bahasa Inggris;

4) Pembuatan media pembelajaran berbasis digital

c. Penugasan

Kegiatan penugasan berupa penugasan kepada peserta untuk mendisain media pembelajaran interaktif berbasis digital dengan topic/tema sesuai dengan ketertarikan masing-masing peserta. Materi penugasan ini meliputi kegiatan:

1) Mendisain media pembelajaran interaktif berbasis digital;

2) Presentasi terkait media pembelajaran yang telah dibuat oleh masingmasing peserta;

3) Diskusi dan refleksi

d. Post-Intervensi Kuestioner

Merupakan evaluasi dari pelatihan yang telah dilaksanakan secara tertulis. Tujuan pemberian kustioner ini untuk mengetahui tingkat pengetahuan, pemahaman dan pelaksanaan pelatihan

\section{HASIL DAN PEMBAHASAN}

A. Gambaran Umum Masyarakat Sasaran

Yang menjadi sasaran kegiatan pengabdian kepada masyarakat tentang edukasi literasi digital ini adalah guru-guru SMP di kabupaten Nganjuk. Guruguru SMP ini adalah mereka yang mengampu mata pelajaran Bahasa Inggris. 
Guru-guru tersebut tergabung dalam suatu organisasi Musyawarah Guru Mata Pelajaran (MGMP). Melalui MGMP ini para guru melakukan berbagai aktifitas terkait pembelajaran Bahasa Inggris termasuk sharing sosialisasi, workshop, koordinasi kegiatan dan sebagainya. Dengan partisipasi berkegiatan dalam MGMP tersebut para guru kurang lebih memiliki pengetahuan dan keterampilan dalam hal pembelajaran Bahasa Inggris yang sama.

Menurut hasil penjajakan awal ditemukan bahwa para guru sudah mengenal beberapa platform media ajar berbasis internet dan digital. Mereka secara umum sudah memanfaatkan aplikasi whatsapps, telegram, google classroom dan sudah menggunakan video pembelajaran dalam melaksanakan tugasnya sebagai guru salah satunya mengajar. Namun mereka masih memerlukan peningkatan pada aspek yang lain diantaranya adalah pengorganisasian materi ajar agar lebih mudah tersampaikan kepada siswa dengan lebih baik dan lebih memotivasi siswa untuk belajar

B. Potensi Pengembangan (Pemberdayaan) Masyarakat

Para guru SMP di Kabupaten Nganjuk sudah terbiasa mengajar dengan laptop atau computer. Rata-rata merka menggunakan poer point presentation untuk menjelaskan materi ajar kepada siswa. Sejak diberlakukannya pembelajaran secara daring para guru mulai memanfaatkan aplikasi-aplikasi yang memungkinkan dapat dengan mudah diakses dan dimiliki oleh semua siswa misalnya whatsapps, telegram, google classroom, google meet dan lain-lain namun masih terbatas pada sosmed dan platform yang kita kenal secara umum.

Berikut merupakan gambaran kondisi kemampuan literasi digital para guru-guru yang diperoleh dengan menyebarkan angket dalam bentuk "GoogleForm" sebelum pelaksanaan pelatihan.

Pertanyaan pertama tentang bagaimana pemahaman guru-guru tentang media digital dan internet. Dalam hal pemahaman ini ada kurang dari setengah responden $(45.7 \%)$ menyatakan bahwa mereka memahami media digital dan internet dengan baik, $40 \%$ sisanya menyatakan ragu-ragu $(40 \%)$ dan sisanya (14\%) menyatakan dengan tegas bahwa pemahaman mereka terhadap media digital dan internet masih sangat kurang. Data lengkap tentang pendapat responden dapat dilihat pada diagram berikut ini;

Diagram 1. Tingkat Pemahaman Peserta terhadap Media Digital dan Internet

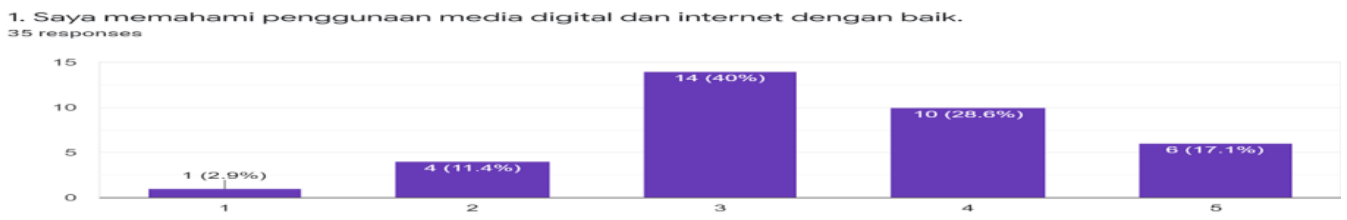

Dari diagram diatas dapat diketahui bahwa sebagian besar guru-guru mempunyai pemahaman media digital dan internet yang perlu ditingkatkan lagi. Maka pelatihan terhadap media digital dan internet masih sangat diperlukan. Walaupun mereka menyatakan sering mengikuti pelatihan tentang literasi digital 
(31\%) tapi mayoritas guru-guru jarang mengikuti pelatihan untuk meningkatkan kemampuan literasi digital. Hal ini ditunjukkan pada diagram berikut ini;

Tabel 2. Frekwensi Guru-Guru Dalam Mengikuti Pelatihan Literasi Digital

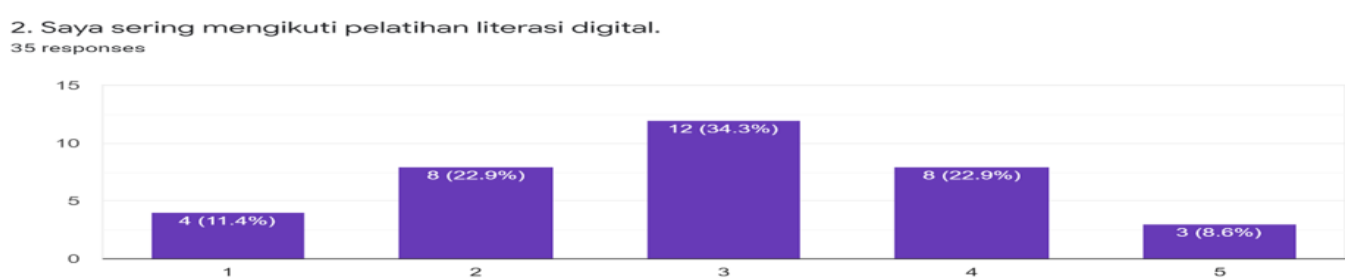

Dari hasil diatas menguatkan tentang pentingnya pelaksanaan pelatihan literasi digital bagi guru-guru. Dari pelatihan-pelatihan yang mereka ikuti, guruguru sangat bersemangat untuk menerapkan dan memanfaatkan hasil pelatihan tersebut dalam pembelajaran. Secara umum (51\%) guru menyatakan bahwa mereka menerapkan ilmu dan ketrampilan yang mereka peroleh dalam pelatihan dalam proses belajar mengajar. Tabel 3 menggambarkan data tentang bagaimana tindak lanjut yang guru laksanakan setelah mereka mendapatkan pelatihan tentang literasi digital.

Tabel 3. Penerapkan hasil pelatihan literasi digital tersebut dalam pembelajaran

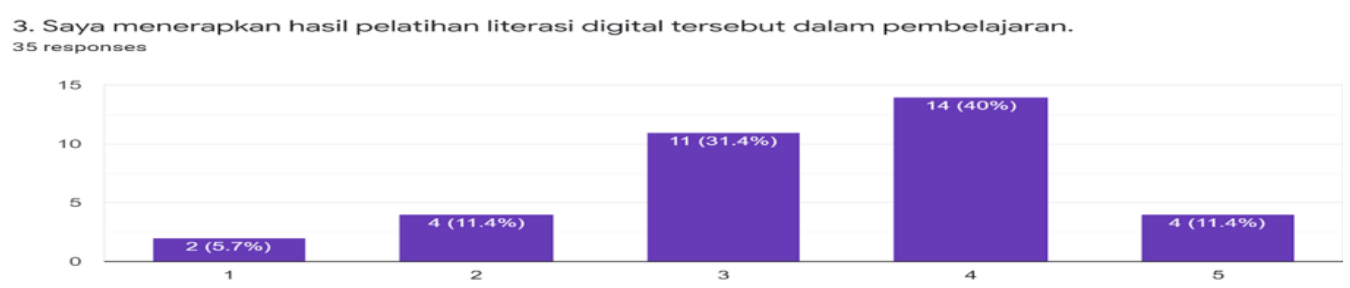

Dari table diatas dapat diketahui bahwa mayoritas guru mampu memahami dan menerapkan pengetahuan dan ketrampilan yang mereka dapatkan ketika mereka mengikuti pelatihan tentang literasi digital. Sebagian kecil saja (17\%) guru yang secara jelas belum menerapkannya. Tentang bagaimana mereka memanfaatkan pengetahuan dan ketrampilan dari pelatihan yang mereka ikuti, tabel 4 menggambarkan tentang kondisi tersebut.

Tabel 4. Pemanfaatan Pelatihan literasi digital dalam pembelajaran

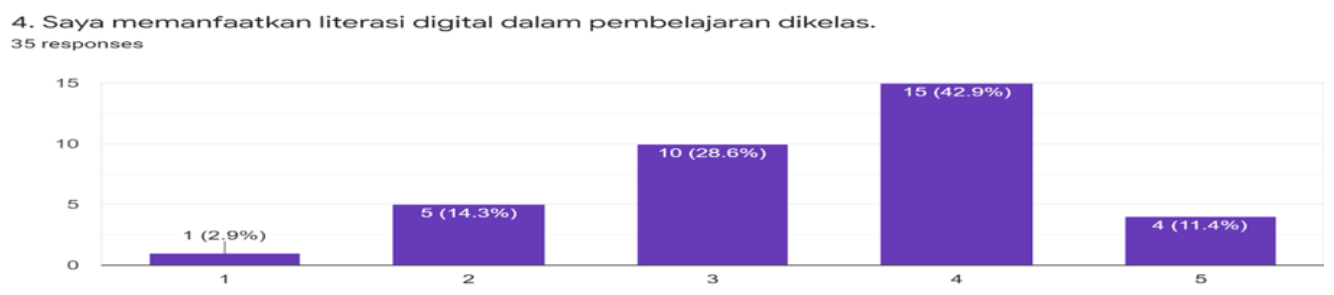

Dari tabel diatas dapat diketahui bahwa mayoritas (52\%) guru menerapkan materi yang mereka dapatkan dalam proses belajar mengajar setelah pelatihan yang mereka ikuti. Jadi secara ringkas dapat disimpulkan bahwa potensi yang mereka miliki masih perlu di upgrade dengan pengetahuan dan keterampilan 
tentang penggunaan teknologi informasi dalam pembelajaran, sehingga akan memudahkan jalannya pembelajaran Bahasa Inggris baik bagi guru maupun siswa.

Maka pelatihan untuk meningkatkan kemampuan literasi guru-guru ini dilaksanakan untuk mempermudah pelaksanaan proses pembelajaran bahasa Inggris. Dalam pelatihan ini pengertian mudah adalah materi terdeskripsikan dengan sistematis dan lengkap, dapat dibaca siswa tanpa harus terhubung dengan internet dan bahkan tanpa membawa buku tebal yang berat.

Selain memudahkan dalam pengertian tersebut, materi ajar juga dibuat lebih menarik agar memotivasi siswa untuk rajin mempelajarinya. Misalnya dengan memvariasinya dengan berbagai macam tampilan seperti ada gambar, ada audio, ada video, ada bagan atau grafik dan lain sebagainya. Dengan begini materi ajar akan menurunkan rasa kebosanan pada guru dan siswa. Untuk itu sasaran perlu dibekali pengetahuan dan keterampilan tambahan yang dapat digunakan untuk meningkatkan kualitas pembelajaran.

C. Solusi Pengembangan (Pemberdayaan) Masyarakat dan Tingkat Ketercapaian Sasaran Program

Dalam pelaksanaan PKM ini, para guru di berikan pelatihan berupa workshop pembuatan materi ajar dengan menggunakan media literasi digital book Next-flip. Workshop dilaksanakan tiga kali dengan scenario pemberian pre-intervensi kuestioner, edukasi literasi, penugasan dan post-intervensi kuestioner. Setelah pelatihan peserta diminta mengisi kuestioner yang bertujuan untuk mengetahui pendapat mereka tentang pelaksanaan pelatihan dan juga memberikan evaluasi tentang jalannya pelatihan.

Hasil Analisa data menunjukkan bahwa dari sisi materi peserta merasa tertarik dengan materi pelatihan.

Tabel 5. Materi Pelatihan

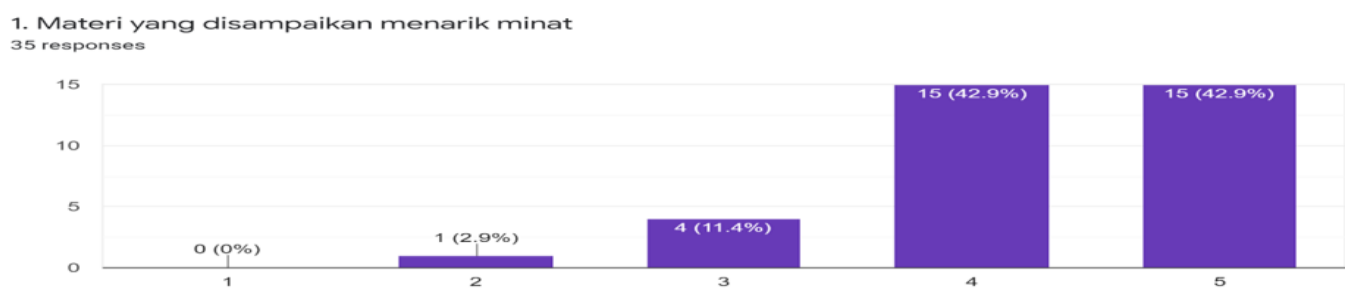

Dari tabel diatas dapat diketahui bahwa materi tentang pennggunaan applikasi next-flip sebagai media pembelajaran menarik minat guru, dimana lebih dari $80 \%$ peserta menyatakan materi pelatihan menarik perhatian mereka. Salah satu factor utamanya adalah adanya kesesuaian antara materi pelatihan dengan kebutuhan guru. Hal ini bisa dilihat dari respon mereka terhadap pertanyaan apakah materu pelatihan sesuai dengan kebutuhan guru-guru. Tabel 4.6 menunjukkan bahwa Sebagian besar peserta $(85.6 \%)$ menyatakan bahwa mereka membutuhkan materi pembelajaran digital ini. 
Tabel 6. Kesesuain Materi Pelatihan dengan Kebutuhan Peserta

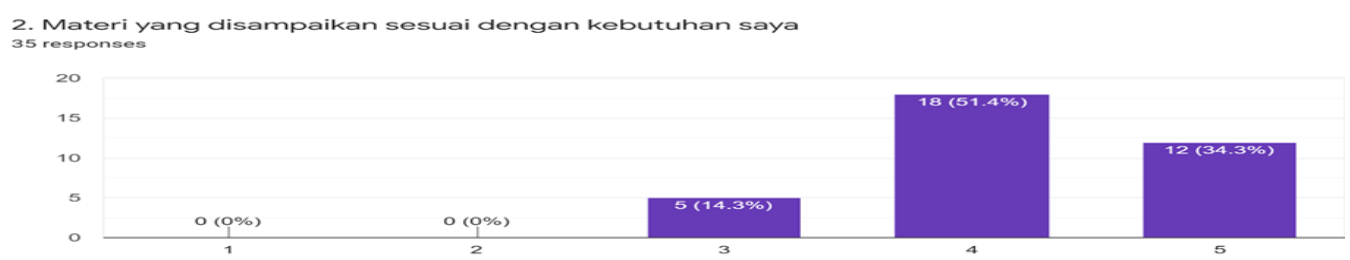

Selain kesesuaian dengan kebutuhan guru, materi yang disampaikan juga mudah dipraktekan sehingga dapat diterapkan dalam pembelajaran sehari-hari dikelas. Data tentang pendapat guru tentang hal ini dapat dilihat pada tabel 4.8 berikuit ini:

Tabel 7. Penerapan Materi Pelatihan dalam Pembelajaran

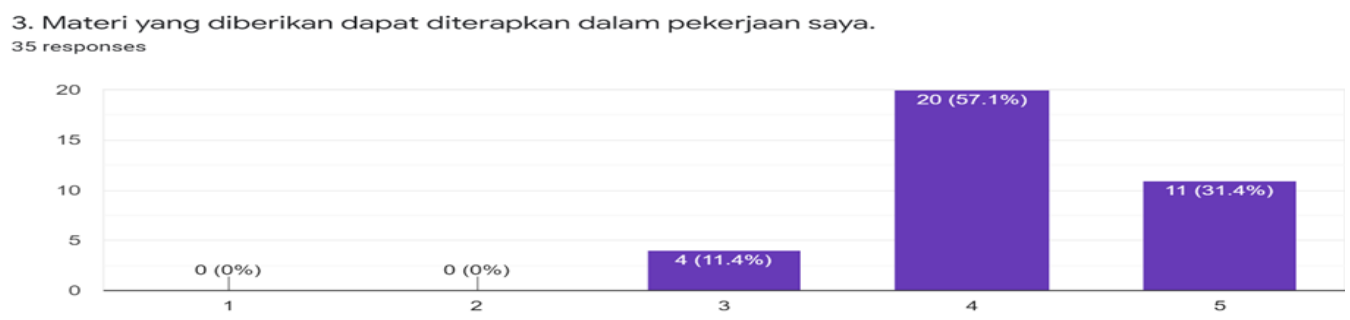

Mayoritas guru (94\%) dapat menerapkan aplikasi next-flip dalam proses belajar mengajar. Mereka tidak mengalami kesulitan dalam menggunakan aplikasi ini di kelas. Kegiatan pengabdian kepada masyarakat ini berusaha untuk menyebarluaskan ilmu pengetahuan, teknologi dan seni kepada masyarakat. Kegiatan tersebut diharapkan mampu memberikan suatu nilai tambah bagi masyarakat, terutama bagi guru-guru SMP di Kabupaten Nganjuk.

Kegiatan pengabdian ini harus mampu memberi perubahan bagi para guru maupun Lembaga sekolah baik jangka pendek maupun jangka panjang. Untuk mencapai tujuan tersebut dilakukan kegiatan workshop atau pelatihan sedemikian rupa agar para guru benar-benar mendapatkan manfaat dari kegiatan ini. Adapun indicator pencapaian tujuan dan tolak ukur yang digunakan untuk menyatakan keberhasilan dari kegiatan pengabdian yang dilakukan adalah partisipasi target sasaran dalam kegiatan ini dan telah dipraktikkannya ilmu dan teknologi yang telah dilatihkan.

Hasil analisa data juga menunjukan bahwa peserta sangat terbantu dan termotivasi untuk merancang media pembelajaran digital seperti yang telah disampaikan pemateri. Mereka menyarankan agar kegitan pelatihan yang berkaitan dengan IT dalam pembelajaran ini dapat diadakan lagi terutama pembuatan video pembelajaran yang menarik.

\section{KESIMPULAN}

Kegiatan pengabdian kepada masyarakat telah dilaksanakan dalam bentuk workshop pembuatan materi ajar Bahasa Inggris dengan menggunakan aplikasi 
nextflip. Para guru SMP di kabupaten Ngajuk berjumlah 71 orang adalah penerima manfaat dari kegiatan ini. Guru Bahasa Inggris di Kabupaten Nganjuk mengetahui manfaat digital book sebagai media pembelajaran Bahasa Inggris pada proses belajar mengajar. Peserta dapat menggunakan fitur-fitur yang disediakan sebagai media pembelajaran yang tidak terpaku pada teks materi saja tetapi dapat juga media yang lain yang dapat diintegrasikan ke dalam buku tersebut. Peserta dapat memanfaatkan teknologi informasi sebagai media untuk mencerdaskan peserta didik dan peserta didik dapat kreatif memanfaatkan media pembelajaran sebagai pendukung proses belajar. Seluruh peserta sepakat bahwa Digital book akan membantu proses belajar mengajar dan akan memanfaatkan aplikasi nextflip untuk mengajar siswa-siswi didiknya. Tugas guru Bahasa adalah untuk menemukan cara inovatif untuk menggunakan kesempatan baru untuk membuat pembelajaran Bahasa inggris lebih efektif dan menarik. Selain itu juga untuk mempertahankan kualitas pembelajaran Bahasa inggris serta nilai-nilai pembelajaran konvensional. Sebagai catatan, guru akan menghadapi tantangan-tantangan misalnya:

1. Berjalan beriringan dengan perkembangan teknologi. Dengan banyaknya perubahan yang sangat cepat ini guru harus mampu mengimbangi dengan memilih media baik berupa perangkat keras maupun lunak yang mampu membuat pembelajaran lebih efektif.

2. Guru harus belajar menggunakan media baru sebagai alat pembelajaran yang berarti ketrampilan baru yang sering dengan cepat di kuasai siswa

3. Memahami cara-cara siswa belajar media baru

4. Mengembangkan metodologi yang dapat mengintegrasikan media baru dalam pembelajaran sebagai fitur efisien dalam kurikulum dan silabus

5. Melengkapai penggunaan media baru dengan media lain yang merupakan bentuk-bentuk input

Untuk itu, system Pendidikan tradisional dirasa sangat penting untuk mengakomodasi kebutuhan belajar generasi baru yang merupakan digital natives maupun siswa yang bukan generasi digital tetapi ingin membuat belajar lebih fleksibel.

\section{DAFTAR PUSTAKA}

Darmawiguna, I. G. M., Pradnyana, I. M. A., Santyadiputra, G. S., \& Pradnyana, G. A. (2019). Pelatihan Dan Pendampingan Pembuatan Media Pembelajaran Interaktif Menggunakan Prezi Dan Videoscribe Bagi Guru-Guru Di Smk Negeri 1 Nusa Penida. Jurnal Widya Laksana, 8(1), 43-50. Retrieved from https://ejournal.undiksha.ac.id/index.php/JPKM/article/view/15584

Erlangga, H. (2021). Effect Of Digital Marketing And Social Media On Purchase Intention Of Smes Food Products. Turkish Journal of Computer and Mathematics Education (TURCOMAT), 12(3), 3672-3678.

Firmadani, F., Shalima, I., \& Al Firdaus, M. M. (2017). Pelatihan Pembuatan Media Pembelajaran Interaktif Dengan Ispring Presenter Bagi Guru Mi Al Islam Balesari Kecamatan Windusari Kabupaten. Conference on Language and Language Teaching, 170-177. 
Hakim, L., Lefudin, L., Ratnaningdyah, D., \& Sugiarti, S. (2020). Pelatihan Pembuatan Multimedia Interaktif sebagai Alternatif Media Pembelajaran. EDimas: Jurnal Pengabdian Kepada Masyarakat, 11(1), 38. https://doi.org/10.26877/e-dimas.v11i1.4295

Kemendikbud. (2017). Buku Panduan Implementasi Kecakapan Abad 21 Kurikulum 2013 Di SMA. Dit. PSMA Ditjen Pendidikan Dasar dan Menengah.

Lesmana, C., Hartono, H., Hartono, H., Permana, R., Permana, R., Matsun, M., \& Matsun, M. (2018). Pelatihan dan Pendampingan Pembuatan Media Pembelajaran Berbasis Multimedia Interaktif Untuk Guru Smp Negeri 1 Sungai Kakap. Al-Khidmah, 1(2), 61. https://doi.org/10.29406/alkhidmah.v1i2.1216

Macromedia, B., Mx, F., \& Situasi, B. A. (n.d.). Pelatihan Pembuatan Media Pembelajaran Interaktif Berbasis.

Pemerintah RI. (n.d.). Undang-Undang Nomor 20 Tahun 2003 tentang Sistem Pendidikan Nasional.

Pujawan, K., \& Restami, M. (2018). Pelatihan Pembuatan Media Pembelajaran Untuk Guru Kecamatan Busungbiu. Selaparang Jurnal Pengabdian Masyarakat Berkemajuan, 1, 18. https://doi.org/10.31764/jpmb.v1i2.458

Yuangga, K. D., \& Sunarsi, D. (2020). Pengembangan media dan strategi pembelajaran untuk mengatasi permasalahan pembelajaran jarak jauh di pandemi covid-19. JGK (Jurnal Guru Kita), 4(3), 51-58. 